\title{
The Disintegration and Reconstruction: How the Western System Reshape the Islamic System
}

\author{
Tian Wenlin \\ China Institutes of Contemporary International Relations (CICIR), Beijing, China
}

Email address:

tianwenlin89@163.com

\section{To cite this article:}

Tian Wenlin. The Disintegration and Reconstruction: How the Western System Reshape the Islamic System. International Journal of Business and Economics Research. Vol. 8, No. 1, 2020, pp. 1-11. doi: 10.11648/j.history.20200801.11

Received: October 11, 2019; Accepted: October 29, 2019; Published: January 10, 2019

\begin{abstract}
Since modern times, the influence and shaping of the Western dominated international system on the Islamic world is very obvious, and the consequences are very serious. But up to now, scholars at home and abroad have limited discussion on this issue. The author tries to answer the above questions. According to author's opinion, under the long-term influence of the western system, the Islamic world has passively carried out "system transformation". It including three major aspects: Firstly, the Western countries used the "one nation-one state view" to disintegrate the empire system of the multi-ethnic coexistence of the Islamic world; Secondly, the Western countries use the "sovereign state view" to dispel the "national state view" that the Middle East countries have just established; Finally, the Western countries have eroded the "sovereign supremacy" principle through various new interventionist theories. As a result, the Islamic world has gradually disintegrated the originally self-consistent Islamic system, thereby bringing irreparable and catastrophic consequences.
\end{abstract}

Keywords: Western System, Islamic System, Deconstruction, Reconstruction

\section{Introduction}

After entering the modern era, European countries have become the center of the world power stage by virtue of the historic opportunities which brought about by the great navigation and industrial revolution. The Islamic world has missed the era of power shift, and it has gradually turned from prosperity to decline. Islamic world is only 200 years behind the west, but in those 200 years the West has changed more than it did in the 2,000-odd years between ancient greco-roman times to the 18th century. Along with the emerging of military and economic power of Western countries, the cross-cultural exchange between the West and the Islamic world has become a one-way penetration of Western values into the Islamic world.

Among them, the influence of the Western international system on the Islamic international system is complex and far-reaching. The reality of fragmentation of European geography determines the geopolitical strategy and strategic culture of the West/Europe. Its basic characteristics are "dividing": splitting, separation, and division. This characteristic has greatly influenced and shaped the geopolitical ecology of the Islamic world, and this has brought a series of serious consequences.

\section{2. "Nation-state System" in Western VS "Empire System" in Islamic World}

\subsection{Background: "Nation-state System" as a Special Case in Western World}

In the modern times, the first round of conceptual impact facing the Islamic world is the transformation and reshaping of the original imperial system of the Islamic world by the Western "national state system." The "nation-state system" (also known as the "sovereign state system") was born out of the "Westphalian System" formed after the European Thirty Years War (1618-1648). The main feature of this international system is that the world is divided into different sovereign states, none of them recognize the existence of the highest authority; individual states are responsible for the formulation and implementation of laws, and disputes are resolved; international law aims to establish minimum rules for coexistence; all countries should be equal; international law only provides minimum protection, and differences between countries are often resolved by force. [1] 
The " Nation-State System" can become the "standard" political unit of the European continent, and in the final analysis is a special product of the specific geopolitical environment in Europe. During the Roman Empire (27 BC 395 AD), the European continent was once geographically unified, with its borders from Spain, Gaul and Britain in the west, the upper reaches of the Euphrates River in the east, and the north to the north of Africa, the North Rhine and the Danube. The area is the country with the largest land area in the ancient history of the world (about 5 million square kilometers). In 395 A. D, Theodosius I divided the empire between his two sons, and the Roman Empire split into two and implemented permanent division. After the collapse of the Western Roman Empire in 476, Europe has since fallen into a state of "small country forests". In the 8 th century A. D, the Charlemagne Empire (also known as the "Carolingian Empire") briefly unified Europe, with its territory southwest to the Ebro River, north to the North Sea, east to the Elbe and Danube, and south to the northern half of Italy. But the Charlemagne empire split during the third generation of inheritance. The three grandsons of Charlemagne signed the Treaty of Verdun in 843, dividing the entire empire into three, and the European reunification process was once again interrupted.

The "Holy Roman Empire" established in 962 seems to govern all of Europe, but in reality it does not really form a unified country. After the 13th century, the Habsburg dynasty tried to expand its sphere of influence, but "all Europe is worried that it will become a world-wide monarchy" and they rebelled. The result was the thirty years' war of 1618-48. The final result of this war was the peace of Westphalia, which made the division of European territory permanent and legal. In the 800 years, when the Charlemagne ruled Europe, there were fewer than ten countries on the Western European continent. By 1300, the number of countries had reached more than 200. [2] This fragmented geopolitical map gradually forms a "nation-state system" that continues to this day by strengthening the differences between different ethnic groups and the internal identity of the nation.

In a certain sense, the concept of a nation-state of "one nation, one state" is the poppy flower that grows on the fragmented political map of Europe. Its impact on the continent and the outside world has been mixed.. Some scholars have pointed out that the logic of the operation of the sovereign state system in Western Europe has threefold: the recognition of politics and identity politics among members of the system, the structural competition within the system, and the dynamics of the system's external expansion. The result of this set of operational logic is to deepen the opposition, division and reorganization of the powers within Europe, and to expand the Western European state system from Western Europe. [3]

\section{2. "Nation State System" Undermine the Empire System in the Islamic World}

In contrast, the international system of the Islamic world is more of an empire system. The Abbas dynasty established in
$750 \mathrm{AD}$ promoted religious tolerance, established the equal system of Muslim compatriots, converted the Arab empire into an Islamic empire, and then determined the unique Islamic world order view and the Islamic world system. [4] Whether in theory or in practice, the Islamic world system is very different from the Western European system that has arisen in the future. There is a great conflict. Since then, the Ottoman Empire, which was founded in 1299, has maintained a unity of more than six hundred years. The other two Islamic powers (Shafawi, Mughal) are also traditional dynasty, thus keeping the Islamic world system Ancient times continued to modern times. This kind of international system is actually an empire system that is above the national level. "In Europe, the end of the great migration allowed the territorial countries to gradually consolidate, and their people succumbed to the tighter control of feudal lords, dynasty rulers and their priests and allies. In the Islamic world, the creation of the 'world empire' and the smaller A fiercely turbulent pattern between tribes or dynasties." [5]

Before the concept of "national state" in Europe was introduced into the Islamic world, there was no concept of "nation" in the region with political identity. In the Ottoman Empire, ethnic groups are more religiously dependent (Muslim, Orthodox, Catholic, Judaism) than national identity (Turks, Arabs, Kurds, Albanians, Armenians, Romanians, Greeks) And the Slavs) to distinguish. [6] Here, the people are most concerned about whether the other person believes in Islam and whether it is a Muslim. "If it is a Muslim, it is basically equal to other Muslims regardless of blood and geographical background. It shares the protection and care of Allah, Muhammad and the Caliphate. If it is not Muslim, it is regulated according to Islamic law." "[7] In 1912, a British diplomat was surprised to find: "All Muslims, whether Shiite or Sunni, Turks, Arabs or Kurds, are registered as 'Muslims' on the household registration book." [8]

The Turks are rulers of the Ottoman Empire, but "in the Ottoman society, the ethnic name of Turkey is almost no longer used; and when this name is used later, it mainly contains contempt, meaning nomadic The Turkmen, or at a later stage, refer to the rude and ignorant peasants who speak Turkish in the Anatolian countryside." [9] Non-Muslims such as the Greeks and Bulgarians do not value language and ethnic differences, but rather value their common beliefs - the Orthodox Church. For Christians in the Ottoman Empire, whether they are Serbs, Bulgarians or Greeks is almost meaningless.

The Ottoman Empire's view of the state is very different from that of Europe, but its political logic is self-consistent. In the Ottoman Empire, the "nations" who practice different languages and believe in different religions are more a standard of occupation than a basis for political independence. The origins of the Ottoman ruling elite reflect this characteristic: the Greeks dominate the bureaucracy, the Christian Marmuluk (slave soldiers) are rising in the military and political high ranks, and the Arab aristocracy and religion Leaders living in the Turkish province are the link between the state and society. [10] This unique mode of operation 
effectively links the political elites and people of different regions of the Ottoman Empire with the imperial capital of Constantinople. Therefore, although the ethnic composition of the Ottoman Empire is complex, the ethnic groups are basically peaceful. This unique "Islamic World System", which once dominated the Middle East for more than 1,000 years, has shaped the worldview of Muslims in the Middle East and their special understanding of human political organization and operational norms. [11]

Undoubtedly, compared with the "nation-state" armed with the concept of "nationalism", the multi-ethnic Ottoman Empire has much worse cohesion. European nationality, nationalism and broken sovereign states interact and promote each other. Compared with a smaller city-state and a larger empire, the nation-state can achieve the optimal match between the efficiency of domination and the cost of governance, helping the people to maximize their recognition and loyalty to the country. In Western Europe, As well as the development of authoritarian regimes, the emergence of a middle class eager for unity and order, the popularization of literacy and the development of new technologies for mass propaganda and education, Western Europe has developed a highly integrated state structure, and its rulers and the ruled have an unprecedented close relationship. Therefore, "in the next two centuries (referring to the 19th and 20th centuries), diplomatic achievements mainly belonged to countries with strong national cores, such as France, Britain, and even Russia, not those loosely organized empire, such as Austria and Turkey." [12]

In contrast, in the Islamic world system, The nations of the empire had a weak sense of community. They were like potatoes in the same sack. They are like potatoes in the same sack, seemingly intertwined with each other, but in reality they lack each other. The Ottoman Empire is vast, with inconvenient transportation and complex ethnic groups. There are cracks between Muslims and Christians, even among Turkish Muslims and Arab Muslims, and between Christian sects. "In countries with these shortcomings, the seeds of recession have long been embedded in its basic organization. [13] This congenital deficiency of the identity system makes it difficult to resist the erosion and expansion of the nation-state system from Western Europe.

And that's true. Since the modern times, with the rapid development of the industrial revolution, Europe has increasingly become the center of world power, and the national state model that supports the fragmented geopolitical pattern of the region has become the object of active or passive imitation of Asian and African countries, and has become the standard of international relations. [14] In 1798, Napoleon invaded Egypt, under the banner of "national liberation." By 1914, the West had not only penetrated into the economic field of the Ottoman Empire, but also infected it with nationalist bacteria, self-doubt and overwhelming spirit and material weakness. [15]

\subsection{Consequence: Disintegration of the Ottoman Empire}

However, "one person's deliciousness is another person's poison." The nation-state system based on the formation of "one nation, one state" was originally a reflection of the concept of broken geographical territory in Europe. "The development of the concept of national sovereignty is at the heart of the process of mutual recognition between nations, whereby the states mutually recognize each other's jurisdiction in their respective territories and communities." [16] In other words, the Westphalian system emphasizes "divide": differentiation, division and even spliting. "Nationalism is far from increasing political stability and political freedom, but creating tension and mutual hatred." [17] Once this view of the international system with congenital defect gene is taken as a "panacea" and brought to non-western countries, especially to the mixed ethnic Ottoman empire, it is bound to become a bitter orange.

The multi-ethnic mixed Austro-Hungarian Empire is deeply touched by the dangerous and catastrophic consequences of the "nation-state" thinking. In 1853, the Austrian Foreign Minister warned: "The idea of establishing a new country based on the nation is the most dangerous of all Utopian plans." "The idea is to sever the relationship with history. Implement it in any part of Europe, It will shake the foundations of a solid and organized national order that will subvert and disrupt the continent." [18]

The Ottoman Empire, which is also a multi-ethnic country, is even more fearful. This is because ethnic groups are often distributed on both sides of the Ottoman border: Romanians, Serbs and Croats, across both Habsburg and Turkey; Romanians, Kurds and Armenians are in Russia. The inhabitants of these provinces have little affinity for the Ottoman empire This ethnic mixed is not a problem in itself. Most of the time these peoples have nothing to do with each other, but if measured by the "national system", almost every ethnic group has become a potential time bomb. In September 1862, the then Ottoman Foreign Minister Ali pointed out in a letter to the Ambassador to France, "'What would happen to Turkey if all different peoples were allowed to pursue the freedom they desire, I am afraid it will have to be spent A century of blood flow into a river, the situation can be stabilized a little." [19]

This is ultimately unfortunate. Europe's economic and military victory has made its "national state" system and "sovereignty" concept increasingly infiltrating and damaging the Ottoman Empire. Under the impact of "national thoughts", ethnic minorities in the Ottoman Empire were increasingly encouraged. "These minorities maintain close contact with the national brothers outside the empire.... For these new 'nationalists', identity must be found in territorial sovereignty, not in church membership. In this case (The Thommamat reform of the Ottoman Empire) It is impossible to realize that the Christian Church accepts shared Ottoman or 'Turkish' citizenship and eliminates differences in mutual loyalty to Sudan." [20]

From the perspective of geo-expansion, European powers have not hesitated to use these "time bombs" to expand their own interests. When Napoleon entered Greece in 1797, he asked General Tilly to use the nationalism of the Greeks to 
conquer the Ionian Islands: "If residents tend to be independent, then we will try to encourage their emotions without hesitation. Talking about Greece, Athens and Sparta." [21] Every attempt to control the colonial powers of the Ottoman region will enhance their ethnic and religious separation, and the trend of resistance against the people under their rule will become more intense. [22] This nationalist "virus" was first transmitted to the Greeks and then to the Serbs and Romanians. In 1815, Sudan was forced to recognize Serbian autonomy; in 1821, Greece launched an uprising for independence, and Britain, France and Russia intervened in the Greek war; in 1829, Sudan was forced to sign the Edna Treaty, recognizing Greek independence, giving Moldavia and Varan The autonomy of the Principality of Guinea (Romania).

Greek independence hit the Ottoman Empire the heaviest. For the first time, although Turkey had a precedent for ceding the territory, it was the first time that the imperial country was officially separated from it by armed struggle. It has played a huge demonstration role in the development of the national liberation movement within the Ottoman Empire. [23] Greek independence is like the first domino that was pushed down, opening the gap in the torrent of the Ottoman national separatist movement. In a wave of national liberation movements, the complex Ottoman Empire collapsed like a paper house: in the late 19th century, Romania, Serbia, and Mende Negros were independent and permanently separated from the Ottoman Empire; 19th Century 90 In the 1980s, Macedonia and Armenia became the focus of the Ottoman national conflict. The Balkans became the "European Gunpowder Barrel". "All Balkan countries want to get back the "unrecovered" brothers or homeland outside the boundaries of the powers." [24] Driven by the dream of expanding the territory, the Balkans broke out two Balkan wars in the early 20th century and transformed the third Balkan war into the first world war, which eventually led to the complete disintegration of the Ottoman Empire.

Finally, even the Arabs who are loyal to the Ottoman Empire also have a national separation appeal. There is no such thing as "the Arabian peninsula" in Arabic, nor the concept of "Arab nation". People living in this land call themselves "bedouins." Their identity and loyalty come from a big family, clan or tribe. But in order to put pressure on the Ottoman Empire, the United Kingdom sowed the seeds of the "nation" among the Arabs, incited the Arabs to carry out the rebellion, and expressed their willingness to support them in the war of independence against the Ottoman Empire. [25] This led to the emergence of a revolutionary ideology in the Arab world under the banner of "nationalism" against the Ottoman rule and for independence. In the end, even the Turks appeared "Turkish nationalism."

It can be said that political nationalism provides an untimely thing for non-Western culture. The premise of the "nation state" is the organic connection between the ruler and the ruled, including the public responsibility of the manager and the civic responsibility of the manager. In the value system, the national state view is actually based on individualism. On the contrary, the political and cultural evolution of most non-Western societies cannot satisfy the primary conditions of national nationalism. In these dynasties and empire, the authorities and the people are more of a relationship of "ruling and obedience", and the people appear more as "subjects" rather than "citizens." The introduction of the theory of the nation state directly impacts the legitimate foundation of imperial rule. The penetration of the concept of Western "nation state" in Asia and Africa has brought more problems than solved. [26]

Zhang Ximo, a Taiwanese scholar, pointed out that the introduction of national ethics directly impacts the justification of imperial rule. When the theory of Islam was subtly abandoned, the Ottoman Empire lost its transcendental ideology integration tool. Nationalism as a new integration principle is more exclusive, and those excluded "others" are bound to be forced to find their own confrontational theories, to find, discover or try to create their own people, as a challenge to the imperial domination and resistance to others. The weapon of the new oppressed group that comes from the name of the nation. In this way, the principle of coexistence and the principle of mutual exclusion, the Pandora's Box and the opening of mutual exclusion and confrontation, finally made the Ottoman Empire face an irreparable split fate. [27]

The facts show that the Ottoman Empire is the victim and victim of this Western-style view of the state. Nationalism of all sorts worked like a ticking time bomb to bring down the pieces of the Ottoman empire. [28] It is estimated that by 1872 , the total population of the Ottoman Empire was about 29 million (except Egypt), more than half of which lived in the European provinces of the Empire. Among them, nearly half of the population is non-Muslim. By 1906, the Ottoman population had fallen to 21 million, and the non-Muslim population accounted for about a quarter of the total population. [29] The western nation-state system eventually weakened, disintegrated, and even replaced the imperial system of the islamic world in the Middle East.

Some hindsight historians complain that the Ottoman Empire accepts the European model (especially the nation-state model) too slowly. In fact, the Ottoman Empire was only on the road to self-destruction because it accepted these "foreign doctrines." The facts show that the process of transplanting the Western-style national system is also a process of vendetta, war and turmoil in the Islamic world.

After the end of World War I, US President Wilson clearly stated the principle of "national self-determination" at the meeting in Versailles. This principle seems to be full of idealism, but in fact it is hidden. It is not only to disintegrate the Ottoman Empire and the Austro-Hungarian Empire, but also to faintly target the British-French colonial rule. According to statistics, at the end of the Second World War, the empire outside the British mainland (except for nominally independent countries within the British sphere of influence, such as the former Italian colonies under the jurisdiction of Egypt, Iraq, and the United Kingdom) totaled approximately 13 million square miles and had a population of more than 550 million. The colonies directly under the control of the United States (including the Philippines) have only 125,000 square 
miles and a population of 19 million. The powerful and ambitious United States has only a limited colony, and the waning British Empire has a vast colony that controls a large number of markets, routes, raw materials and investment sites. This contrast and contradiction is the main reason for the hostile relationship between imperialism. [30]

Therefore, some analysts believe that Wilson "vigilant and even jealous of its (United Kingdom) national strength." [31] At that time, the United States believed that "the United States should not be interested in helping Europe to restore its pre-war status. It is not for this old-fashioned obsolete goal. It is more urgent to contribute to reshaping the future world and bring it to the real world. Change." [32] In this context, advocating national self-determination and letting the people who "succumb to the authority" rise up against it can weaken the influence of the colonial empire such as Britain and France. However, from the perspective of objective effects, this has made the concept of "nation-state" increasingly popular in the world.

At first, Arab intellectuals did not agree with this "national state view" with separatism. But after the outbreak of World War I, the British provocation made the Arabs' sense of independence increasingly recover. At the same time, the Zionist organization has set Palestine as a habitat for Jewish people, seeking to build a "national homeland" and will be supported by Western powers from the beginning. In this context, the Arab nationalism that advocates the establishment of a "unified Arab country" is becoming more and more popular. It consists of three closely related ideological elements: Nasserism (named after Egyptian President Nasser), Baathist (named after the Arab Baath Socialist Party), and the Arab Nationalist Movement (named after the same name organization of students from the University of Beirut in 1952). Despite the differences, the three all called for the liberation of Arab territories, the realization of independence, and the path of socialist development. [33] All such an international system based on the "nation-state view" has rebuilt the Islamic world system that has lasted for hundreds of years.

\section{3. "Sovereign States System" in Western VS "Nation State System" in the Arab World}

\subsection{Sovereign State System: The New Weapon of Imperialism}

Advocating a sovereign state system may mean independence, liberation and freedom for the rest of the world, but it is more of a disaster than the gospel for the Arab world. It stands to reason that the application of the principle of "one nation, one state" to the Arab world can produce a geopolitical effect contrary to European political practice: in the European region, broken geopolitics is established in accordance with the principle of "one nation, one state". [34] The Arab people born from the ruins of the disintegration of the Ottoman
Empire, because of the large number of people, occupy the vast territory of West Asia and North Africa. Therefore, if the state is founded according to the principle of "one nation and one nation", the Arab nation will have the complete possibility to establish a "greater Arab state" that reaches to Alexandria in the north, to the border of Iran in the east, to the Persian gulf in the south, and to the red sea and Mediterranean Sea in the west, which will become an important power in international politics.

This result is clearly unwilling to be seen by Western powers. At the beginning, the European powers instilled the concept of "nation state" and the "nation-state system" into the Eastern world, mainly to weaken and disintegrate the complex system of the Ottoman Empire, rather than "propagating advanced civilization" and liberating the various ethnic groups in the Ottoman Empire. Not to cultivate opponents for yourself. It is not difficult to understand that on the critical issue of the reconstruction of the geopolitical system in the Middle East, Britain and France broke the promise made by British high commissioner John McMahon and hussein in 1915-16 to "establish a united Arab state", and the principle of "one nation, one nation", which had been repeatedly advocated. Instead, they used "self-determination" to create a new political system expanding their sphere of influence -"mandate". [35] According to the Sykes-Picotte Agreement, which was secretly reached in Britain and France in 1916, Britain and France eventually divided the entire Arab world into a number of "appointing ruling countries" and incorporated the Middle East directly into its colonial system. Therefore, from the perspective of subtle influence or political coercion, the Middle East international system has been branded as "Made in the West" since its birth.

On the other hand, part of the connection between "mandate" and "self-determination" encouraged nationalists in the trust areas to build up their own state, and this national liberation movement just produced several "sovereign states" along the map drawn in advance by Britain and France. In other words, the british-french regional system for arabs is not based on the oft-repeated emphasis on "nation-states" but on "subnation-states" based on the principle of "mandate."In this way, the geopolitical structure of the Middle East, originally conceived as a unified "Arab nation state", has become a fragmented system of "sovereign states in the Middle East".

After the end of World War II, the United States and the Soviet Union replaced Britain and France and became the largest extraterritorial country with the greatest influence on the order in the Middle East. In the early post-war period, traditional colonial systems such as Britain and France still existed, which greatly hindered the role of the United States and the Soviet Union in global affairs. For the two superpowers of the United States and the Soviet Union, although they are real opponents in the long run, in the circumstances, the common task they faced was to try to dismantle the global colonial system dominated by Britain and France, so as to free up space for the US-Soviet game. Out of space. Just as Britain, the dominant economic power in the 19 th century, favored "free trade imperialism" in order to enter 
the world market, for the same reason, the United States, the dominant economic power in the 20th century, favored anti-colonial imperialism with the aim of Imposing his own rule on the heads of the people who have just been liberated from British oppression.

In order to achieve this goal, the United States and the Soviet Union jointly promoted the "decolonization" movement. As early as the end of the Second World War, Roosevelt and Stalin jointly advocated the principle of "national self-determination" and made it one of the basic principles of international law. Roosevelt stressed: "The United States and the Soviet Union are not colonial powers. We are more likely to discuss these issues. I think the colonial empire will not exist for a long time after the end of the war." [36] In the eyes of American leaders, these colonial empire are reactionary, inefficient, and conservatively backward, but "worse, they create economic isolation, close the door to open trade to the United States, and hinder US export growth." [37]

The British are well aware of this. British Foreign Secretary Anthony Eden mentioned in his memoirs: "(Roosevelt) hopes that once the former colonies are freed from their masters, they will be politically and economically attached to the United States." [38] French leader Charles de Gaulle also sees very well that Roosevelt supports the colonial independence of the world, and these newly independent and feather-free countries will certainly rely on the United States to spend the day. The personnel and decision-making of these governments will also receive Washington and Roosevelt. Remote command. [39] The "cold war" against the Soviet Union was open to the expansion of imperialism in the United States, while the "cold war" against the British Empire was hidden. Although the words of respect and friendship are disguised, the latter "cold war" is as true as the former "cold war." This is consistent with the more powerful US imperialist attempts to dominate and weaken the older European imperialist countries, especially its main rival, British imperialism. " [40]

In any case, the two superpowers of the United States and the Soviet Union jointly advocated national self-determination and "decolonization", which made the national liberation movement flourish and objectively made the national state system that began in Europe a global system. According to statistics, during the period of 1940-1980, more than 80 European overseas colonies gained independence, involving a population of about $40 \%$ of the world's total population. [41]

\subsection{Sovereign State System Reshape the Regional System of Middle East}

Specific to the Middle East, the British-French colonial rule system also gradually disintegrated: France abandoned its appointment to Lebanon in 1945; the British abolished the appointment of foreign Jordan (renamed Jordan after December 1949) in 1946, acknowledging it as an independent kingdom. A year later, Britain abandoned its right to appoint Palestinians. [42] In 1956, Britain and France were defeated in the Suez Canal War, completely ending the period in which Britain occupied a dominant position in the hinterland of the Middle East for nearly a century, marking the "decisive failure of veteran imperialism in the Middle East." [43] By the 1950s and 1960s, Britain and France had gradually faded out of the central position of the political arena in the Middle East.

However, "the front door drives the wolf and the back door enters the tiger." The vacuum of power left by the British and French colonial powers was quickly replaced by two new superpowers. As I said before, the United States and the Soviet Union advocated "national self-determination" and "decolonization", mainly to weaken the British-French colonial system, rather than really interested in the liberation of the third world. Therefore, in the face of the geopolitical order of the Middle East established by the English and French disruption of the "rules of the game", the United States and the Soviet Union did not "real", but proceeded to the geopolitical game along the new map of the Middle East divided by the British. No matter how the United States and the Soviet Union compete for the Middle East, they have intentionally or unintentionally ignored the political demands of the Arabs to establish a "national state." The "national liberation movement" of the Arab world in the 1950s and 1960s was actually "man-made national self-determination" rather than " The self-determination of the Arab nation, the Middle East system established on this basis, is not a "national state" in the true sense, but a "sovereign state" in the sense of international law.

The consequence of this is that the organizational principles of the Arab region are not a given premise, but a competitive concept. On the surface, the Middle East is an anarchy composed of sovereign states, but the two transnational ideologies of Arab nationalism and Islamism have been trying to transform the region from a sovereign state system left over by European colonists to a unified nation state. And even higher levels of theocracy.

The legal principle of "nation-state" and the boundary of "sovereign state" do not overlap, leading to the Arab countries in the "nation" and "state" between the drift, the Arab world disputes. Some scholars have correctly pointed out that in the Arab world, "the external inconsistency between the state and the nation leads to revisionism of a nationalistic nature (such as Arab nationalism and islamic fundamentalism); The incongruity between states and nations leads to the lack of cohesion within Arab countries.

This revisionism interacts with non-cohesion within the country, making the region particularly prone to war. [45] This is the root cause of the turbulence in the Arab region since the disintegration of the Ottoman Empire. [46] The Saddam regime is a typical example. He first took the "Nationalism" banner to the stage, and then he became a "Merbairen patriarch", then later became a "Muslim Unity", and finally under the banner of radical secularism, trying to annex and pursue "feudalism." Kuwaiti regime. [47]

In short, in the case that the Islamic world system has collapsed and the "national and national consciousness" of the various ethnic groups in the Middle East is recovering, what these countries need most is to construct a "imaginary community", but the "appointment rule" adopted by Western countries such as Britain and France. However, it led to the national construction of 
the Middle East, which ultimately led to the fragmentation of power distribution in the Middle East countries.

\section{Neo-interventionism Destroy "Sovereign State System" in the Middle East}

\subsection{Sovereign State System as a Secondary Choice for Arab States}

In the Arab world, the 1950s and 1970s was an era of tug-of-war between the "sovereign state view" and the "nation-state view." During this period, Arab nationalism represented by Nasserism advocated Arab unity and unity. The Arab world has also tried many rounds of state mergers. It is a pity that these merger attempts ended in failure. In the 1970s, with the death of Nasser in 1970 and the succession of Sadat's successor, the Middle East gradually abandoned the "Arab nationalism" advocated by Nasser and turned to the banner of "Egyptian First". [48] The typical event is that Egypt disregards the opposition of other Arab countries and is alone with Israel: Sadat visited Israel in November 1977; in 1978, Egypt signed the "David Camp Agreement"; in March 1979, Egypt and Israel signed a peace agreement.

The practice of "sweeping the snow before the door" in Egypt has led Jordan and other countries to follow suit, achieve peace with Israel, and suffer a major setback in the Arab reunification of the Arab world. This means that the Arab countries have reluctantly recognized the "Westphalian-style" regional system, and the people in power no longer seek to achieve Arab unity, no longer seek to establish a unified "Arab country", and begin to recognize the status quo, and Learn to use the principle of "sovereignty is inviolable" to safeguard the rights and interests of the country and counter the infiltration of Western hegemony. In a sense, "sovereignty first" has become the last firewall for the Middle East countries to safeguard their rights and interests.

\subsection{Neo-interventionism Damage the Sovereign State System in the Middle East}

However, "the plan can't keep up with the changes." Although the Middle East countries have followed suit, trying to emulate and adapt to the rhythm of the impact of the external international system and enter the era of sovereign states, this does not mean that the troubles of the Middle East countries have ended. The pace of adaptation of the Middle East countries to the international system seems to be always "slowly half-shooting", and it is always unable to catch up with the West's pursuit of hegemony: when the Ottoman Empire adapted to the "one nation, one state" principle, it abandoned the Islamic world system that lasted for thousands of years; When people tried to establish a unified "Arab country" in accordance with the "nation-state" principle, the Western powers dismembered the Arab world in accordance with the "appointment rule", making it a sovereign international system with small countries; when the Arab countries in the Middle East decided to give up "national states" After dreaming and reluctantly adapting to the "sovereign state system" in line with Western strategic design, the principle of "sovereignty is inviolable" has begun to face the challenges of Western neocolonialism and neo-imperialism. Since the principle of "sovereignty is inviolable" has become a hindrance to the Western powers in the Middle East. the next step of western powers is to find ways to eliminate the legitimacy and legitimacy of the principle of sovereign states.

In this context, the flawed sovereign state is prevailing, and the "national centralism" is gradually surrounded by various new interventionist theories.

\subsubsection{Emphasizing the Substitution of "Global Politics" for "Sovereign Politics"}

The globalization process itself is a challenge to the state-based Westphalian system and the global political order based on realism. On the one hand, various international organizations and non-state actors emerge in an endless stream, objectively posing a great challenge to the traditional status of sovereign states. According to statistics, in 1948, there were only 69 official non-governmental organizations under the UN, but by 2015, there were more than 4,000 non-governmental organizations. The mission of many non-governmental organizations is to safeguard "human rights". [49] This directly erodes the legitimate rights and interests that traditionally belong to sovereign states. On the other hand, economic globalization has prompted the rapid growth of Western transnational capital. According to statistics, 51 of the world's top 100 economies are multinational companies and 49 are sovereign states. The world's 200 largest multinationals have an economy larger than that of 182 countries combined. [50] The behavioral patterns and boundaries of transnational corporations are not limited to issuing orders and conducting unequal exchanges, but directly constructing and integrating territories and populations, thus posing a great challenge to the status of sovereign states. "The huge industrial and financial forces not only produce goods but also produce the main body. They tend to turn the nation-state into a simple tool whose function is simply to record and count the goods, money, and population exchanges driven by them. In fact, it determines the new ecological political structure of the world." [51]

In this context, the United States put forward the "failed state theory" in the mid-1990s, arguing that weak and failed states can cause terrorism, regional chaos, criminal activities, diseases and environmental disasters, posing a major threat to the United States. The United States must take the initiative to "go out" to stabilize these countries and help them build their country. This theory poses a direct challenge to the principle of supremacy of sovereignty in backward countries. The United States' definition and intervention in Afghanistan and Somalia is a typical example.

\subsubsection{Overriding Abstraction Principles (Such as Human Rights, Democracy, etc.) Above National Sovereignty}

This view holds that the provisions of powers and 
constraints, rights and responsibilities established by international law have greatly restricted the principle of state sovereignty, so that "sovereignty" is no longer a direct guarantee of international legitimacy. The most typical is the "human rights doctrine", which claims that "human rights have no borders", "a legitimate country must be a country that maintains certain common democratic values" and "human rights are higher than sovereignty." The International Human Rights Charter, the Convention on the Elimination of Discrimination against Women, the Convention on the Rights of the Child, and the Declaration on the Rights of Persons Belonging to Ethnic Minorities, Ethnicity, Religion and Language adopted by the UN General Assembly in 1992 have all become human rights protections. Source of international law. "International human rights can be seen as an unauthorized violation of the internal affairs of the country." [52]

After entering the $21 \mathrm{st}$ century, the concept of "Responsibility to Protect" (R2P) has become popular. The theory emphasizes that it is not only the "responsibility to respond" but also the "responsibility to prevent" and the "responsibility for reconstruction". These expressions imply the possibility of political change in other countries. A scholar of the US Foreign Relations Committee believes that for more than three hundred and fifty years, "the border is inviolable" and "monopoly use of force" has always been the official mark of sovereignty. Adopting the "responsibility to protect" is a watershed in the international community, marking The end of the sovereign era. [54]

\subsubsection{Abusing of the Concept of "Just War" Against the Sovereign State System}

The "just war" is easy to beautify and ethical war, so in the international society composed of sovereign states, this practice has been strictly restricted or even completely rejected. But in recent years, this concept has become popular. The status of war has been weakened into a form of police action that is increasingly becoming a mandatory way that can be easily initiated. At the same time, war acts are endowed with ethical significance, and countries that wage war are increasingly sanctified. "It has become an activity that provides legitimacy for itself. First, as long as there is an ethical basis, military measures have legitimacy. Second, military operations to achieve order and peace of desire are effective. The combination of these two components can indeed be a key element that will determine the foundation and new traditions of the empire." [55] The resurrection of the concept of "just war" is a sign of the emergence and external manifestation of the new imperial system led by the United States. Its threat to the disadvantaged third world countries (including the Middle East countries) is becoming more direct and obvious.

This situation was most evident after the end of the Cold War. After the collapse of the Soviet Union's camp, the Western countries headed by the United States were the only ones in the international system. The United States was eager to reshape the world order according to its own wishes. In order to interfere in the internal affairs of the third world countries, the Western countries concocted various kinds of rulings (such as possessing weapons of mass destruction, humanitarian disasters, government dictatorships, etc.) and smashing the principle of "sovereignty is not allowed to interfere" in order to break through the political power of the third world. The last "amulet" of survival provides a veritable way for Western countries to interfere in his internal affairs.

The theoretical point of view is different from foreign policy, but once the theory is accepted by the ruler, it will be transformed into a reality policy. These theories, which question the status of sovereign states, are themselves generated in response to the real needs of western powers. Once they appear, they are sought after by Western powers and become the theoretical accomplices of Western powers interfering in the internal affairs of third world countries. "Supernational institutions can intervene in any emergency or in the name of ethical values. The legitimacy of such actions is not supported by legal rights, but by international consensus. In other words, universal values legitimize police power." [56]

The United States is the initiator of new interventionism, and The Middle East is the epicenter of the new interventionism. After the end of the Cold War, the United States became the world's only superpower. The expansion of the country's strength made the United States' hegemonic ambitions increasingly expand, and the impulse to interfere in other countries was growing. American scholars have proposed different strategic blueprints such as "Clash of Civilizations", "End of History", "The Great Country Tragedy", "Failed State Theory", and "Game Rules". "The big strategy of the United States is to identify the geopolitical fault line and find out where potential global forces are about to emerge and collide with each other, creating the places and ways that ultimately lead to major conflicts, and finding ways to overcome the fault line. Or at least find ways to reduce the damage potential of the fault line." [57]

\subsection{The Middle East Countries: The Victims of Neo-interventionism}

The 1991 Gulf War was the beginning of the practice of interference theory in the United States. The outbreak of the "9.11" incident prompted the United States to further use the Middle East as a strategic breakthrough to establish a "new world order" and to replace political power as the main means to achieve this goal. [58] The Bush administration's interference in Middle East affairs mainly follows the two main lines of policy: The first is to carry out "democratic transformation" in the Middle East by inheriting the neo-conservative school of Wilson school. The Wilson school regarded ideology as a decisive factor, derived various ideas such as "democracy leads to peace" and "tyranny breeds terror", and believed that the spread of democracy was the top priority of American diplomacy. The United States has repeatedly urged traditional allies such as Saudi Arabia and Egypt to carry out political reforms and try to rebuild Iraq as a "Middle East Democracy Model." The United States forcibly "democracy transformation" of other countries directly poses 
a threat to the sovereign state system. Second, according to the Jackson School, the use of force in the Middle East to promote hegemony benefits. The Jackson School emphasizes that in order to realize the interests of the United States, it can be used to achieve its goal. According to this deduction, since terrorism is the greatest threat to current US interests, it is necessary to use force to eradicate it. To this end, the United States has established a "preemptive strike" strategy of martial arts. The United States itself determines who is a "rogue state", a "failed state" or an "axis of evil", and judges whether it is threatened by these countries and then carries out military strikes against it. This makes the United States override the basic norms of international law and fundamentally denies the principle of "sovereign state equality."

The 2001 Afghanistan War and the 2003 Iraq War were the United States' direct war against two independent sovereign states in the name of "anti-terrorism" and made the United States' influence deep in the heart of Central Asia and the Middle East. In 2011, after the turmoil in Libya, the United Nations adopted the Resolution 1973 on the establishment of a no-fly zone in Libya in the name of "responsibility to protect" and authorized member states to "take all necessary measures" to protect Libyan civilians. According to this, the British and French launched a continuous air strike against Libya, which eventually overthrew the Qaddafi regime. The "responsibility to protect" has become a cover for Western countries to push the executive power replacement strategy. [59] After Trump took office in 2017, on the grounds of Syria's alleged use of chemical weapons, two missiles were fired at targets in Syria, and the principle of "sovereignty is not allowed to interfere" was flagrantly trampled, which in turn aggravated the deep disaster of the Syrian crisis.

\section{Summary}

In the modern times, under the continuous impact of the Western international system, although the Middle East countries have followed suit and tried to imitate and adapt to the impact of the Western-led international system, they have always been "slowly half-shooting" in the face of the West's pursuit of hegemony: when the Ottoman empire abandoned the islamic world system lasting for thousands of years to adapt to the European-style "one nation, one state" principle, resulting in the final disintegration of the multi-ethnic Ottoman empire; when the independent Arab nation from the ruins of the disintegration of the Ottoman Empire tried to establish "one nation, one state" principle In the Arab countries, Britain and France were strong but disfigured the Arab world in accordance with the "appointment rule", making the Middle East a "balkanized" sovereign international system; when the Arab countries paid a huge price, they decided to give up the "national state" dream and reluctantly When adapting to the "sovereign state system" shaped by Western strategic interests, the Western powers have also launched new interventionism of various brands, constantly questioning and challenging the "sovereignty inviolability" principle and even the sovereign state system, thereby making the Middle East countries continue to suffer from the Western Hegemonic powers. This is the tragedy of the Middle Eastern countries and the epitome of the tragic fate of many Asian, African and Latin American countries.

Further analysis, the reason why the western international system could erode and reshape the international system of the Islamic world that was caused by the strength gap between the two sides. Before modern times, the western world and the Islamic world were close to each other, so the cross-cultural exchanges between the two sides were also mutual exchanges and mutual shaping. However, after entering modern times, European countries took the lead in catching the fast train of industrial revolution, while the Islamic world missed it, which led to the strength of both sides is changing and the decline of the Islamic world. In this context, the Islamic world increasingly imitated everything from the West (including the concept of state, political system, etc.) as the key to achieve prosperity and strength. Hundreds of years later, when the Islamic world realized the negative effects of copying the western system, the western style system had been deeply embedded in the Middle East countries, making the Islamic world face the dilemma of "unable to go back to the past, unable to see the future".

\section{References}

[1] [UK] David Helder waits, Yang Xuedong and other translations: "Global Change: Politics, Economy and Culture in the Age of Globalization", Social Sciences Academic Press, 2001, pp. 51-52.

[2] Yang Luteng Fanzan Deng, translated by Fu Fumin: "The Long Way to the Industrial Revolution: The European Economy in the Global Perspective (1000-1800)", Zhejiang University Press, 2016, p. 41.

[3] Zhang Ximo: "Jihad and Civilization: The Eternal Conflict between Islam and the West", Sanlian Bookstore, 2014, p. 112.

[4] Zhang Ximo: "Jihad and Civilization: The Eternal Conflict between Islam and the West", Sanlian Bookstore, 2014, p. 55.

[5] John Darwin, Lu Weifang, Gao Fangying: "After the post of $\mathrm{Mu}$ Er: The rise and fall of the global empire", Elephant Press, 2011, p. 30

[6] Stavrianos: "Global Split" book, Chi Yue, Wang Hongsheng, etc., Huang Xiqun, Luo Rongqu School, Commercial Press, 1995, p. 117.

[7] Zhang Ximo: "Jihad and Civilization: Eternal Conflict between Islam and the West", Sanlian Bookstore, 2014, p. 64.

[8] Mark Mazor, translated by Liu Huiliang: "Balkan: Misunderstood "European Powder Library", Tianjin People's Publishing House, 2007, p. 41.

[9] Bernard Lewis: The Rise of Modern Turkey, translated by Fan Zhonglian, The Commercial Press, 1982, page 8.

[10] Raymond Hinnebusch, The International Politics of the Middle East, Manchester University Press, 2003, pp. 15-16. 
[11] Zhang ximu. Jihad and civilization: the eternal conflict between Islam and the west. Sanlian bookstore, 2014, p. 9.

[12] Barbara Jelavic: "The First Century of Russian Foreign Policy: 1814-1414", Translation of the Foreign Languages Department of Fujian Normal University, Commercial Press, 1978, p. 3.

[13] Hilti, translated by Ma Jian: The General History of Arabia, The Commercial Press, 1995, p. 857.

[14] HilalKhashan, Arabs at the Crossroads: Political Identity and Nationalism, University Press of Florida, 2000, p. 21.

[15] D. Edward Knox, The Making of a New Eastern Question (British Palestine Policy and the Origins of Israel, 1917-1925), The Catholic University of America Press, Washington, D. C, 1981, p. 4.

[16] David Helder is waiting, Yang Xuedong and others: "Global Change: Politics, Economy and Culture in the Age of Globalization", Social Sciences Academic Press, 2001, p. 50.

[17] Eric Kaduri, translated by Zhang Mingming, "Nationalism", Central Compilation Press, 2002, p. 110.

[18] Mark Mazor: "The Balkans: Misunderstood "European Powder Library", Tianjin People's Publishing House, 2007, p. 117.

[19] Bernard Luis, translated by Zheng Zhishu, "Middle East: Surging in a Glorious History", China Friendship Publishing House, 2000, p. 416.

[20] John Darwin, Lu Weifang and Gao Fangying: "After the Timur Age: The Rise and Fall of the Global Empire", Elephant Press, 2011, p. 243.

[21] Stavrianos, Chi Yue, Wang Hongsheng, etc., Huang Xiqun, Luo Rongqu School: "Global Split" book, The Commercial Press, 19.

[22] John Darwin, Lu Weifang and Gao Fangying: "After the Timur Age: The Rise and Fall of the Global Empire", Elephant Press, 2011, p. 304.

[23] Edited by Wang Shengzu, History of International Relations, vol. 2, World Knowledge Press, 1995, p. 89.

[24] Balkan: Misunderstood "European Powder Library", p. 98.

[25] Beijing Continental Bridge Cultural Media Compilation: "Middle Wars", World Knowledge Press, 2005, p. 126.

[26] HilalKhashan, Arabs at the Crossroads: Political Identity and Nationalism, University Press of Florida, 2000, p. 23.

[27] Zhang Ximo: "Jihad and Civilization: The Eternal Conflict between Islam and the West", Sanlian Bookstore, 2014, p. 177.

[28] Stavrianos, Chi Yue, Wang Hongsheng, etc., Huang Xiqun, Luo Rongqu School: Global Split, Vol. 121, p. 121.

[29] [German] Robert G. Walter, [United States] Erez Mannes, editor-in-chief, Liang Zhanjun, etc., "Imperial Empire (1911-1923)", People's Publishing House, 2015, p. 24.

[30] Pam Dud, Su Zhongyan, Gui Chengfang, Xi Ming translation: "The British and British Empire Crisis", World Knowledge Press, 1954, p. 141.

[31] Margaret McMillan, Rong Hui, Liu Yanyi Translated: "The Game of the Great Powers: One hundred and Eighty Days to Change the World", p. 15.

[32] Kong Huarun, Zhang Zhenjiang, etc. Translation: Cambridge
History of American Foreign Relations (Volume 2), Xinhua Press, 2004, pp. 40-41.

[33] IDEOLOGY, POLITICAL, MIDDLE EAST, Tutorials and Information.

[34] In fact, the theory of the nation-state in Europe is largely the result of "Sir Child, later name".

[35] Eli Kaduri, translated by Zhang Mingming, "Nationalism", Central Compilation Press, 2002, pp. 128-129.

[36] Vallekin Bereshkov, Xue Fuzhen translation: "Ministers of Stalin's Private Translation", Hainan Publishing House, 2004, p. 245.

[37] John Darwin, Lu Weifang, Gao Fangying, "The Post-Timuer Age: The Rise and Fall of the Global Empire", Elephant Press, 2011, p. 363.

[38] Stavrianos, Chi Yue, Wang Hongsheng, etc., Huang Xiqun, Luo Rongqu School: "Global Division" (below), The Commercial Press, 1995, pp. 667-668.

[39] Conrad Black, Zhang Fan and other translations: "Roosevelt Biography", CITIC Publishing House, 2005, p. 283.

[40] Pam Dud, Su Zhongyan, Gui Chengfang, Xi Ming translation: "The British and British Empire Crisis", World Knowledge Press, 1954, pp. 142, 148.

[41] James Sheehan, translated by Huang Gongxia, "The Decline of Violence", Elephant Press, 2011, p. 151.

[42] Sol Cohen, Yan Chunsong, "Geeopolitics: Geography of International Relations," Shanghai Academy of Social Sciences Press, 2011, p. 372.

[43] Richard Crocker, translated by Wang Zhenxi, "The 50 Years War", Xinhua Press, 2003, p. 260.

[44] Benjamin Miller, States, Nations and the Great Powers: The Sources of Regional War and Peace, Cambridge University Press, 2007, p. 132.

[45] F. GregoryGause III, Systemic Approaches to Middle East International Relation, International Studies Review, Volume 1, Issue Spring 1999, pp. 26-27.

[46] Sol Meng, if not translated: "Islamic Manufacturing", Yunchen Culture Industrial Co., Ltd., 2007, p. 239.

[47] In 1978, when Sadat returned to Israel for peace and peace, the masses wrote on the warmly welcome placard: "The first is Egypt, the second is Egypt, and finally Egypt." See (US) Stavrianos: Global Split, The Commercial Press, 1995.

[48] Gerald M. Steinberg and Joshua Bacon, "NGO Links to Middle East Terror", Middle East Quarterly, Summer 2017.

[49] Graham Vanbergen, "The Rise of the Corporatocracy", Global Research, June 21, 2016

[50] [German] Michael Hart, [Italian] Antonio Negri, translated by Yang Jianguo and Fan Yiting, "Imperial", Jiangsu People's Publishing House, 2005, p. 36.

[51] David Helder, "Global Change: Politics, Economy and Culture in the Age of Globalization", p. 94. Yang Xuedong and others translated.

[52] Ramesh Thakur, "R2P after Libya and Syria: Engaging Emerging Powers", The Washington Quarterly, SPRING 2013, pp. 61-76. 
[53] Michael Hart, [Italian] Antonio Negri, translated by Yang Jianguo and Fan Yiting: Empire, Jiangsu People's Publishing House, 2005, p. 13.

[54] Michael Hart, [Italian] Antonio Negri, translated by Yang Jianguo and Fan Yiting: Empire, p. 18.

[55] Charles Koop is doing, Pan Zhongqi translation: "The End of the American Era", Shanghai People's Publishing House, 2004.
[56] Dr. Ismail Salami, "The Post 9/11 Era and Washington's Dirty Modus Operandi in the Middle East", Global Research, February 9, 2014

[57] JayshreeBajoria, and Robert McMahon, "The Dilemma of Humanitarian Intervention", Council on Foreign Relations, June 12, 2013. 